\title{
Euroopan valtioiden velkakriisimyytin syyt ja seuraukset
}

Pia Ljungman, doctoral candidate, Department of Politics and International Studies, SOAS University of London

Avainsanat: talouskriisit, euroalue, pääomamarkkinat https://doi.org/10.51810/pt.107639

Euroopan valtioiden velkakriisiksi 2010-luvulla kutsutut tapahtumat ja prosessit sekä toimet, joilla kriisiin on poliittisesti vastattu, ovat muokanneet Eurooppaa yli vuosikymmenen ajan. Euroopan velkakriisi ei uhannut pelkästään useiden Euroopan rahaliiton jäsenvaltioiden rahoitusta tai Euroopan unionin talous- ja rahaliiton instituutioiden vakautta vaan myös koko eurooppalaista projektia, Euroopan yhteismarkkinoita ja yhteisvaluuttaa. Eurooppalaiset päättäjät vastasivat kriisiin finanssipoliittisilla toimilla, joilla on ollut merkittäviä ja kauaskantoisia sosiaalisia seurauksia (esim. Arestis ja Sawyer 2012; Blyth 2013). Velkakriisin hoitamiseen tähdänneet poliittiset toimet keskittyivät kuitenkin pääasiassa Euroopan rahaliiton jäsenvaltioiden ja instituutioiden makrotaloudelliseen päätöksentekoon eivätkä käytäntöihin globaaleilla finanssimarkkinoilla. Finanssimarkkinoiden käytäntöjä ovat esimerkiksi yksityiseen pääomasijoittamiseen liittyvät velkarahoitusjärjestelyt sekä kaupankäynti erilaisilla joukkolainoilla, -velkakirjoilla ja johdannaisinstrumenteilla. Päättäjät ja monet valtavirran tutkijat ovat toistuvasti pitäneet näitä käytäntöjä velkakriisin ratkaisuna, mikä on vahvistanut globaalin finanssikapitalismin keskeistä asemaa nykypäivän Euroopan ja maailman politiikassa. Usein itsestäänselvinä pidetyt käytännöt finanssimarkkinoilla ovat siis edelleen olennainen osa laajempaa 
eurooppalaista projektia (esim. Braun ym. 2018; Gabor ja Vestergaard 2018).

Väitöskirjani The Myth of the ESDC. The Causes and Consequences of the European Sovereign Debt Crisis Narrative, 2008-2018 tuo esiin globaalin finanssisektorin roolia Euroopan valtioiden velkakriisikonstruktion syissä ja seurauksissa. Tarkastelen tutkimuksessani Euroopan valtioiden velkakriisikonstruktiota olennaisena osana maailmanlaajuista finanssikriisiä. Tästä näkökulmasta katsottuna kriisin poliittiset syyt ja sosiaaliset seuraukset näyttäytyvät uudessa valossa. Väitöskirjani analysoi ensinnäkin sitä, miten Euroopan velkakriisikonstruktion avulla luonnollistettiin sitä valtajärjestelmää, joka alun perin johti globaaliin finanssikriisiin ja syvään taloudelliseen taantumaan. Toiseksi analysoin sitä, miten globaaleja finanssimarkkinarakenteita ja -käytäntöjä on uusinnettu Euroopan valtioiden velkakriisikonstruktion seurauksena. Empiirinen analyysini korostaa varjopankkisektorin roolia Euroopan valtioiden velkakriisin syissä ja seurauksissa. Analyysini huomioi myös yksityistetyn keynesiläisyyden eli velkarahoitteisen kulutuskysynnän ja siihen liittyvien markkinakäytäntöjen määräävän aseman globaalin sosiaalisen järjestyksen määrittelyssä (esim. Crouch 2013, 2011). Väitöskirjani empiirinen aineisto koostuu media-aineistosta, ylikansallisten ja kansallisten instituutioiden dokumenteista sekä makrotalous- ja finanssimarkkina-aineistosta.

Empiirisen analyysini perusteella esitän neljä toisiinsa liittyvää argumenttia. Ensinnäkin väitän, että finanssimarkkinat ovat poliittisen toimijuuden keskeinen näyttämö ja alan käytännöt ovat luonteeltaan poliittisia. Toiseksi väitän, että erilaiset kriisinarratiivit paljastavat niitä määrittelevien oletusten kautta hallitsevan sosiaalisen järjestyksen, jota monet ihmiset - sekä tutkijat että laajempi yleisö - pitävät usein itsestäänselvyytenä. Kolmanneksi väitän, että Euroopan valtioiden velkakriisiksi kutsuttu tapahtuma oli olennainen osa globaalia finanssikriisiä. Kyseessä oli yksi kriisi, ei kaksi, ja tämän yhden kriisin keskiössä olivat transatlanttisen alueen finansialisoituneet rahoitusmarkkinarakenteet ja -käytännöt. Neljänneksi väitän, että hallitseva myytti Euroopan valtioiden velkakriisistä voidaan ymmärtää hegemonisena poliittisena projektina, jonka avulla on uusinnettu vallitsevaa kansainvälistä valtajärjestystä. Sen keskiössä on yhtäältä Yhdysvaltain dollarin kansainvälinen asema, toisaalta siihen liittyvät rakenteet ja käytännöt globaaleilla finanssimarkkinoilla. 


\section{Kriisidiskurssit poliittisen taistelun ja luokkataistelun näyttämöinä}

Finanssimarkkinoiden käytännöt eivät yleensä ole Euroopan velkakriisistä tehtyjen analyysien keskiössä. Ne ovat kuitenkin melkein aina läsnä kansainvälisissä talouskriiseissä joko suoraan tai epäsuorasti. Onkin vaikea nähdä, miten kansainvälinen talouskriisi voisi syntyä ilman finanssimarkkinoiden nykykäytäntöjä. Globaalit finanssimarkkinat otetaan kuitenkin usein itsestäänselvyytenä - vain osana maailman kiertokulkua -, eikä globaalin finanssisektorin toimijoita nähdä kriisien synnyn keskeisinä tekijöinä eikä itsenäisinä tai poliittisina toimijoina. Euroopan valtioiden velkakriisin hallitsevassa myytissä on samansuuntainen tendenssi. Tässä tutkimuksessa määritän myytin dominantiksi narratiiviksi, jolla on tietyssä kulttuurissa "paradigmaattisen totuuden asema” (Lincoln 1989, 24).

Väitöskirjani analyysin keskeinen tavoite on kyseenalaistaa velkakriisin myytti näyttämällä, miten se on tuotettu. Metodologisesti toteutan tämän tarkastelemalla rinnakkain velkakriisimyytin keskeisiä kriisinarratiiveja ja finanssimarkkinakäytäntöjä sekä näiden välisiä suhteita: jännitteitä, puutteita, ristiriitoja sekä yhteensulautumisia. Myytin, käytäntöjen ja niiden välisten suhteiden tarkastelu tuo esiin sen, millä tavoin yksinkertaistetut poliittispopulaariset kriisinarratiivit usein epäpolitisoivat globaalia finanssimarkkinatoimijuutta. Esimerkiksi vaikka eurooppalaiset pankit ovat olennainen osa sekä niin sanottua Euroopan valtioiden velkakriisiä että globaalia finanssikriisiä, velkakriisimyytti näkee nämä erillisinä tapahtumasarjoina. Euroopan valtioiden velkakriisi nähdään siis yleensä juuri eurooppalaisena kriisinä, joka yhdistetään esimerkiksi Kreikan hallituksen toimiin ja Euroopan rahaalueen finanssipoliittisiin sääntöihin. Globaali finanssikriisi taas jäljitetään usein Yhdysvaltoihin ja Yhdysvaltojen asuntolainamarkkinoiden toimintaan. Näissä kriisinarratiiveissa itsestäänselvyytenä otetut alueelliset erottelut eivät kuitenkaan vastaa globaalien finanssimarkkinoiden käytäntöjä.

Väitöskirjani analyysi perustuu viitekehykseen, jossa kriisit ymmärretään sosiopoliittisina konstruktioina, jotka rakennetaan narratiivien kautta diskursiivisin keinoin. Kriisejä ei siis nähdä diskurssin ulkopuolisina kohteina vaan tapahtumina, jotka diskursiivisesti määritellään merkitsemään kriisiä - eikä jotakin muuta (esim. Hay 1999; Weldes 1999). Kriisille voidaan hahmottaa erilaisia syitä ja kriisin sijainti, kesto ja toimijat voidaan määritellä eri tavoin. 
Mikäli ymmärrämme ihmisten toiminnan riippuvan siitä, miten he määrittelevät erilaiset tilanteet ja tapahtumat, on hallitsevilla narratiiveilla selkeitä aineellisia vaikutuksia, jotka parantavat eräiden sosiaalisten ryhmien asemaa toisten sijaan (esim. Filippini 2017). Tästä syystä kriisidiskurssit ovat sekä poliittisen taistelun että luokkataistelun näyttämöitä. Esimerkiksi globaali finanssikriisi liitetään usein niin kutsuttujen korkean riskin subprime-luottoluokituksen saaneiden asuntolainojen lisääntymiseen ja niiden romahdukseen asuntolainamarkkinoilla. Yhdysvalloissa subprime-luottoluokituksen saaneet olivat pääasiassa vähävaraisia ja rodullisten vähemmistöjen edustajia. Kriisinarratiivi asetti subprime-asuntolainat keskiöön ja alleviivasi edellä mainitun sosiaalisen ryhmän roolia kriisin synnyssä. Tätä kautta kriisinarratiivi uusinsi historiallis-sosiaalisia valtasuhteita ja niihin liittyviä rahoituskäytäntöjä, mikä myös vahvisti yksityistetyn keynesiläisyyden määräävää asemaa.

\section{Kriisinarratiivit sosiaalisen järjestyksen uusintajina}

Kun Euroopan velkakriisiä ja globaalia finanssikriisiä tarkastelee yhtenä kriisinä, käy ilmi, että globaalin finanssisektorin toimijoilla oli keskeinen rooli sen tuottamisessa. Tämä rooli on kuitenkin häivytetty Euroopan valtioiden velkakriisimyytissä. Analyysini tuo esiin sen, että poliittiset toimet kriisin ratkaisemiseksi suosivat finanssisektoria sekä Yhdysvalloissa että Euroopassa. On osittain myytin seurausta, että globaalin finanssikapitalismin sekä rakenteellista että diskursiivista dominanssia ei ole tehokkaasti haastettu Euroopassa. Tämän sosiaalisen hegemonian todisteena toimii myytin asema itsestäänselvänä arkijärkenä (esim. Crehan 2016). Arkijärki ei viittaa erimielisyyksien puuttumiseen vaan pikemminkin itsestäänselvyytenä otettuun maailmankuvaan - siihen, miten ymmärrämme maailman olevan organisoitu ja miten uusinnamme tätä maailmankuvaa.

Kriisinarratiivia, joka nousee hallitsemaan muita niin, että siitä tulee arkijärkeä, on analysoitava vallan funktiona. Analyysini selvittää, miten hallitsevan kriisinarratiivin määräävä asema on syntynyt ja mitkä sen sosiopoliittiset luokkavaikutukset ovat (esim. Laffey ja Weldes 2004). Kriisianalyysit, mukaan lukien Euroopan valtioiden velkakriisianalyysit, kyseenalaistavat kuitenkin harvoin itse kriisin ja kriisin perustavanlaatuisen poliittisen diskursiivisen 
luonteen. Arkijärki määrittää silloin usein myös ne parametrit, joiden puitteissa käymme keskusteluja: kriisin sijainnin, sisällön, ajoituksen ja sen päähenkilöt. Tällä tavoin kriisinarratiivit asettavat ennakko-oletuksia ja ottavat usein itsestäänselvyytenä sen laajemman sosiaalisen järjestyksen, jonka kontekstissa kriisi tapahtuu. Tämän seurauksena kriisikertomukset osallistuvat myös kyseisen sosiaalisen järjestyksen uusintamiseen.

Euroopan valtioiden velkakriisimyytin tunnusomainen piirre on sosiaalinen järjestys, joka keskittyy tiettyihin poliittisiin rakenteisiin ja käytäntöihin, esimerkiksi valtioiden ja instituutioiden talouspoliittiseen ohjaukseen. Samalla myytti häivyttää globaalien finanssimarkkinoiden rakenteet ja käytännöt näkymättömiin, mistä seuraa niiden luonnollistuminen ja epäpolitisoituminen. Velkakriisimyytin - kuten myös globaalin finanssikriisin - keskiössä on diskurssi siitä, miten valtion ja sen instituutioiden tulisi talouspoliittisesti toimia. Tämä diskurssi koskee kuitenkin erityisesti valtiollisten ja institutionaalisten toimijoiden talouspoliittisia vastauksia finanssimarkkinoiden kriiseihin. Valtavirta-analyysin lisäksi olettamus, jonka mukaan valtiot ja instituutiot ovat keskeisiä talouspoliittisia toimijoita, esiintyy myös kriittisessä kirjallisuudessa, mikä edistää Euroopan valtioiden velkakriisimyytin vahvistumista. Näin hegemoninen diskurssi luonnollistaa globaalien finanssimarkkinoiden käytäntöjä ja toimijuutta, mikä tuottaa sosiaalisen järjestyksen, jossa globaali finanssisektori on hallitseva mutta samanaikaisesti näkymätön ja itsestäänselvä.

Kontekstualisoimalla tavanomaiset kriisikertomukset kuvailemallani tavalla pyrin väitöskirjassani tunnistamaan sen, mitä talouspolitiikan päätöksenteon kiistat ovat syrjäyttäneet tai piilottaneet. Pyrin paljastamaan eri konstruktioiden politiikan tuomalla esiin, mitä korostetaan, mitä jätetään pois, miten ajalliset sekvenssit määritellään ja miten tilat liittyvät toisiinsa. Tämän rinnastuksen avulla mahdollistuu toinen samanaikainen analyysitaso, joka perustuu päivittäisiin käytäntöihin finanssimarkkinoilla. Väitöskirjassani rakennan ja kerron Euroopan kriisinarratiivin uudelleen. Tämä paljastaa, millä tavoin Euroopan valtioiden velkakriisimyytti korostaa, peittää tai edistää globaalin finanssikapitalismin vallan rakenteita. En siis ainoastaan kyseenalaista Euroopan valtioiden velkakriisimyytin itsestäänselvyyttä vaan myös kuvaan sen uudelleen tavoilla, jotka tuovat esiin myytin politiikan ja ottavat huomioon sen vaikutukset. 


\section{Yksityisen sektorin ratkaisu ja sen seuraukset}

Purkamalla Euroopan velkakriisimyytin taustalla olevia kriisikertomuksia osoitan, että kriisi oli olennaisilta osiltaan finansialisoitujen transatlanttisten rahamarkkinarakenteiden ja -käytäntöjen kriisi. Kriisin näkökulmasta talouspoliittinen päätöksenteko on ollut suhteellisen yhdenmukaista sekä Yhdysvalloissa että Euroopassa. Empiirinen aineistoni tuo esiin sen, miten Yhdysvaltojen ja Euroopan päättäjät ovat erilaisilla talouspoliittisilla toimilla suosineet finanssisektorin vahvistamista. Talouspoliittiset toimet ovat tukeneet erityisesti ylikansallisia ja globaaleja pankkeja, samalla kun varjopankkisektorille on annettu mahdollisuus järjestellä uudelleen paikallisien lainanantajien taseita niin Yhdysvalloissa kuin Euroopassa - erityisesti euroalueen eteläisissä jäsenmaissa. Kutsun tätä talouspoliittista päätöksentekokehikkoa $\gamma k s i t y i s e n ~ s e k t o r i n$ ratkaisuksi (private sector solution) ja kuvaan, miten se on laajamittaisesti vaikuttanut sekä omaisuuden uudelleenjakoon että finanssimarkkinakäytäntöihin. Kuten väitöskirjastani käy ilmi, suuri joukko poliittisia toimijoita on edistänyt yksityisen sektorin ratkaisua. He ovat toimineet monissa eri konteksteissa mutta jakavat kuitenkin samanlaisen käsityksen maailmasta. He harjoittavat siten käytäntöjä, joiden tarkoituksena on toistaa tietynlaisia sosiaalisia, poliittisia ja taloudellisia järjestelyjä, jotka yleisesti ottaen hyödyttävät kuitenkin globaalia finanssisektoria.

Euroopan valtioiden velkakriisimyytti on vaikuttanut suoraan vallitsevan sosiaalisen järjestyksen uusintamiseen, laajentumiseen ja syventämiseen. Väitöskirjani empiirinen analyysi osoittaa, että Euroopan valtioiden velkakriisimyytti rakensi kansainvälistä talouspolitiikkaa, joka perustui Yhdysvaltojen löyhään rahapolitiikkaan, yhdessä Euroopan rajoittavan finanssipolitiikan kanssa. Tämä talouspoliittinen päätöksentekokehys tuki yksityisen sektorin ratkaisua, joka puolestaan mahdollisti romahtaneiden transatlanttisten rahamarkkinarakenteiden ja -käytäntöjen uusintamisen. Tämän seurauksena monet käytännöt globaaleilla finanssimarkkinoilla ovat siirtyneet Euroopan rahaliiton alueelle, mikä on tukenut varjopankkitoiminnan kansainvälistä laajentumista ja syvenemistä. Tämä on myös muokannut kansainvälisiä valtasuhteita.

Euroopan valtioiden velkakriisimyytin seurauksena ei ole ainoastaan dollarista riippuvaisempi Eurooppa vaan myös velkaantuneempi maailmantalous, 
joka kokonaisuudessaan on yhä enemmän riippuvainen Yhdysvaltain dollarista ja siten myös Yhdysvaltain politiikasta. Yksi Euroopan velkakriisimyytin vaikutuksista oli siis Yhdysvaltain kansainvälisen dollarihegemonian ja siihen kiinteästi liittyvän yksityisen finanssisektorin, erityisesti yksityisen varjopankkisektorin, vahvistuminen. Väitöskirjani yleinen johtopäätös onkin se, että Euroopan valtioiden velkakriisimyytti voidaan parhaiten ymmärtää osana sosiaaliseen luokkaan perustuvaa strategiaa, joka uusintaa ja laajentaa transatlanttisen finanssipääoman poliittisesti määräävää asemaa. Tämä ilmenee yhä tapahtuvana yhteiskunnallisten, poliittisten ja taloudellisten suhteiden uudelleenjärjestelynä Atlantin molemmin puolin.

\section{Lähteet}

Arestis, Philip ja Sawyer, Malcolm. 2012. The Euro crisis. Basingstoke: Palgrave Macmillan.

Blyth, Mark. 2013. Austerity: The history of a dangerous idea. Oxford: Oxford University Press.

Braun, Benjamin, Gabor, Daniela ja Hübner, Marina. 2018. Governing through financial markets: Towards a critical political economy of capital markets union. Competition \& Change, 22:2, 101-116. https://doi.org/10.1177/1024529418759476

Crehan, Kate. 2016. Gramsci's common sense. Inequality and its narratives. Durham: Duke University Press.

Crouch, Colin. 2011. The strange non-death of neoliberalism. Cambridge: Polity Press.

Crouch, Colin. 2013. Making capitalism fit for society. 1 painos. Cambridge: Polity Press.

Filippini, Michele. 2017. Using Gramsci. A new approach. Northampton: Pluto Press.

Gabor, Daniela ja Vestergaard, Jacob. 2018. Chasing unicorns: The European single safe asset project. Competition \& Change, 22:2, 139-164. https://doi.org/10.1177/1024529418759638 
Hay, Colin. 1999. Crisis and the structural transformation of the state: Interrogating the process of change. The British Journal of Politics and International Relations, 1:3, 317-344. https://doi.org/10.1111/1467-856X.00018

Laffey, Mark ja Weldes, Jutta. 2004. Methodological reflections on discourse analysis. Qualitative \& Multi-Method Research, 2:1, 28-30. https://doi.org/10.5281/zenodo.998671

Lincoln, Bruce. 1989. Discourse and the construction of society: comparative studies of myth, ritual, and classification. New York: Oxford University Press.

Weldes, Jutta. 1999. Constructing national interests: The United States and the Cuban Missile Crisis. Borderlines 12. Minneapolis: University of Minnesota Press. 